\title{
Synthesis and Acaricidal Activities of New Benzophenone $O$-Methyloximes
}

\author{
Hiroyuki KaI, ${ }^{*}$ Minoru Tomida, Toru NAKaI, Kinuko Kumano, \\ Shigeki HIROSE and Koichi MORITA \\ Aburahi Laboratories, Shionogi \& Co., Ltd., Koka-cho, Koka-gun, \\ Shiga 520-3423, Japan
}

(Received August 7, 2000; Accepted November 13, 2000)

\begin{abstract}
We synthesized newly developed benzophenone $O$-methyloxime derivatives (I) and assessed their acaricidal activities. Studies of the structure-activity relationship revealed that the strongest acaricidal activity was achieved when position-2 in the left phenyl moiety was substituted with a 5-trifluoromethyl-2pyridyloxymethyl group. Among the geometrical isomers at the oxime moiety, the $Z$-isomers were more active than the $E$-isomers. When the right phenyl moiety was substituted with a $4^{\prime}$-chloro, $4^{\prime}$-bromo or 4 '-trifluoromethyl group, good acaricidal activity was obtained. Among the compounds examined, 4'-chloro-2-(5-trifluoromethyl-2-pyridyloxymethyl)benzophenone $O$-methyloxime (21) showed the most potent activity against Tetranychus urticae and Tetranychus kanzawai.
\end{abstract}

Key words: Benzophenone $O$-methyloxime, ( $\alpha$-alkoxyiminobenzyl)isoxazole, acaricidal activity, Tetranychus urticae, Tetranychus kanzawai.

\section{INTRODUCTION}

In our previous papers, ${ }^{1,2)}$ we reported the structurefungicidal activity relationship of ( $\alpha$-alkoxyiminobenzyl) isoxazole derivatives designed by replacing the carbamoyl moiety in known fungicidal alkoxyiminoacetamide derivatives $^{3-5}$ ) with an isoxazole ring. Our investigations revealed that 3-[2-(2,5-dimethylphenoxymethyl)- $\alpha$-methoxyiminobenzyl]isoxazole ( $\mathbf{A}$ in Fig. 1) exhibited potent activities against cucumber powdery mildew, wheat powdery mildew and wheat eye spot.

In this continued study, the isoxazole ring as well as the phenoxymethyl moieties in compound $\mathbf{A}$ were modified structurally and various biological activities of these novel compounds were examined. It was found that benzophenone $O$-methyloximes (I in Fig. 1) showed potent acaricidal activity against Tetranychus urticae, while these oxime derivatives showed less or no fungicidal activities (unpublished). Since potent acaricidal activities of benzophenone $O$-methyloximes were observed, a series of benzophenone $O$-methyloxime derivatives have been synthesized with various substituents $\left(R^{1}\right.$ on the left phenyl and/or $\mathrm{R}^{2}$ on the right phenyl) to find the optimal structure exhibiting the most potent acaricidal

\footnotetext{
* To whom correspondence should be addressed.
}

activity.

\section{MATERIALS AND METHODS}

\section{Instrumental Analysis}

Melting points were measured with a Büchi 535 melting point apparatus and values given uncorrected. Refractive indexes were measured with an Atago Abberefractometer. IR spectra were taken on a JASCO FT/ IR-300E spectrophotometer using a potassium bromide disk. ${ }^{1} \mathrm{H}$ NMR spectra were recorded on a JEOL JNMGSX 270 spectrometer at $270 \mathrm{MHz}$ using tetramethylsilane (TMS) as an internal standard.

\section{Synthesis of Compounds}

Procedures for the synthesis of benzophenone $O$ methyloxime derivatives are shown in Fig. 2. A typical synthetic procedure was as described below.

\subsection{4'-Chloro-2-(4-trifluoromethylphenoxymethyl)ben- zophenone O-methyloxime: 7 and 12 (Method A)}

To a mixture of $\mathrm{N}, \mathrm{O}$-dimethylhydroxylamine hydrochloride $(3.51 \mathrm{~g}, 36 \mathrm{mmol})$, pyridine $(5.70 \mathrm{~g}, 72 \mathrm{mmol})$ and dichloromethane $(40 \mathrm{ml})$, was added over $30 \mathrm{~min}$ a solution of 2-chloromethylbenzoyl chloride $(5.67 \mathrm{~g}, 30 \mathrm{mmol})$ in dichloromethane $(20 \mathrm{ml})$ below $10^{\circ} \mathrm{C}$, and the mixture was stirred at room temperature for $3 \mathrm{hr}$. The mixture was poured into ice-cold water $(200 \mathrm{ml})$, acidified with 


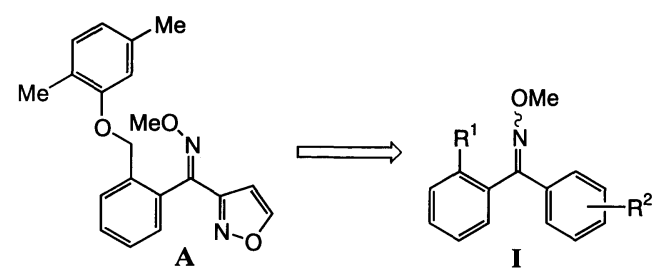

Fig. 1 Chemical structures of compound $\mathbf{A}$ and benzophenone $O$-methyloximes I.

$35 \%$ hydrochloric acid, and extracted with dichloromethane $(100 \mathrm{ml} \times 2)$. The combined organic layer was dried over anhydrous magnesium sulfate and concentrated under reduced pressure to give crude 2-chloromethyl- $N$ methoxy- $N$-methylbenzamide.

A mixture of crude 2-chloromethyl- $N$-methoxy- $N$ methylbenzamide, 4-(trifluoromethyl)phenol $(5.84 \mathrm{~g}, 36$ mmol), potassium carbonate $(6.22 \mathrm{~g}, 45 \mathrm{mmol})$ and $N$, $N$-dimethylformamide $(60 \mathrm{ml})$ was stirred at $50^{\circ} \mathrm{C}$ for 17 hr. The reaction mixture was poured into ethyl ether $(250 \mathrm{ml})$ and washed with brine $(200 \mathrm{ml} \times 2)$. The organic layer was dried over anhydrous magnesium sulfate and concentrated under reduced pressure. The residue was purified by silica gel column chromatography (ethyl acetate/hexane) to give $9.23 \mathrm{~g}(91 \%)$ of $N$ methoxy- $N$-methyl-2-(4-trifluoromethylphenoxymethyl)benzamide II $\left(\mathrm{R}^{1}=4-\mathrm{CF}_{3} \mathrm{C}_{6} \mathrm{H}_{4} \mathrm{OCH}_{2}\right)$ as a colorless oil. ${ }^{1} \mathrm{H}$ NMR $\left(\mathrm{CDCl}_{3}\right) \delta \mathrm{ppm}: 3.29(3 \mathrm{H}, \mathrm{s}), 3.53(3 \mathrm{H}$, s), $5.20(2 \mathrm{H}, \mathrm{s}), 7.00-7.04(2 \mathrm{H}, \mathrm{m}), 7.35-7.55(6 \mathrm{H}, \mathrm{m})$.

To a mixture of magnesium $(0.73 \mathrm{~g}, 30 \mathrm{mmol})$, bromoethane $(0.1 \mathrm{ml})$ and tetrahydrofuran $(3 \mathrm{ml})$ was added a solution of 1-bromo-4-chlorobenzene $(3.83 \mathrm{~g}, 20$ mmol) in tetrahydrofuran $(17 \mathrm{ml})$ at 50 to $55^{\circ} \mathrm{C}$ under a nitrogen atmosphere, and the mixture was stirred at 50 to $60^{\circ} \mathrm{C}$ for $1 \mathrm{hr}$ to prepare 4-chlorophenyl magnesium bromide III $\left(\mathrm{R}^{2}=4-\mathrm{Cl}\right)$.

The Grignard reagent III $\left(\mathrm{R}^{2}=4-\mathrm{Cl}\right)$ was added to a solution of $\mathbf{I I}\left(\mathrm{R}^{1}=4-\mathrm{CF}_{3} \mathrm{C}_{6} \mathrm{H}_{4} \mathrm{OCH}_{2} ; 3.39 \mathrm{~g}, 10 \mathrm{mmol}\right)$ in tetrahydrofuran $(10 \mathrm{ml})$ below $-50^{\circ} \mathrm{C}$ over $20 \mathrm{~min}$, and the mixture was stirred at $-50^{\circ} \mathrm{C}$ to room temperature for $3 \mathrm{hr}$. The reaction mixture was poured into ice-cold water $(150 \mathrm{ml})$ and saturated aqueous ammonium chloride solution $(50 \mathrm{ml})$, and extracted with ethyl ether $(200 \mathrm{ml})$. The organic layer was dried over anhydrous magnesium sulfate and concentrated under reduced pressure. The residue was purified by silica gel column chromatography (ethyl acetate/hexane) to give $2.91 \mathrm{~g}$ (74\%) of 4'-chloro-2-(4-trifluoromethylphenoxymethyl) benzophenone (IV ; $\left.\mathrm{R}^{1}=4-\mathrm{CF}_{3} \mathrm{C}_{6} \mathrm{H}_{4} \mathrm{OCH}_{2}, \mathrm{R}^{2}=4-\mathrm{Cl}\right)$ as a white solid, $\mathrm{mp} 75-76^{\circ} \mathrm{C}$. ${ }^{1} \mathrm{H}$ NMR $\left(\mathrm{CDCl}_{3}\right) \delta \mathrm{ppm}$ : $5.25(2 \mathrm{H}, \mathrm{s}), 6.67(1 \mathrm{H}, \mathrm{d}, J=7.6 \mathrm{~Hz}), 6.83(2 \mathrm{H}, \mathrm{d}, J=8.8$ $\mathrm{Hz}), 7.40-7.48(6 \mathrm{H}, \mathrm{m}), 7.54-7.58(1 \mathrm{H}, \mathrm{m}), 7.72-7.74$ $(2 \mathrm{H}, \mathrm{m})$.

A mixture of $\mathbf{I V}\left(\mathrm{R}^{1}=4-\mathrm{CF}_{3} \mathrm{C}_{6} \mathrm{H}_{4} \mathrm{OCH}_{2} ; \mathrm{R}^{2}=4-\mathrm{Cl}\right.$; $0.39 \mathrm{~g}, 1.0 \mathrm{mmol})$, methoxylamine hydrochloride $(0.25 \mathrm{~g}$, $3.0 \mathrm{mmol})$, pyridine $(0.26 \mathrm{~g}, 3.3 \mathrm{mmol})$ and ethanol $(2$ $\mathrm{ml}$ ) was heated under reflux with stirring for $8 \mathrm{hr}$. The mixture was poured into ice-cold water $(80 \mathrm{ml})$, acidified with $35 \%$ hydrochloric acid, and extracted with ethyl ether $(100 \mathrm{ml})$. The organic layer was dried over anhydrous magnesium sulfate and concentrated under reduced pressure. The residue was purified by silica gel column chromatography (ethyl acetate/hexane) to give $0.25 \mathrm{~g}$ (60\%) of compound 7 ( $Z$-isomer) as a white solid, $\mathrm{mp}$ $65.5-66.5^{\circ} \mathrm{C}$ and $0.12 \mathrm{~g} \mathrm{(29 \% )} \mathrm{of} \mathrm{compound} 12(E-$ isomer) as a white solid, $\mathrm{mp} 78-80{ }^{\circ} \mathrm{C}$. Compound 7 ; Anal. Found : C, $62.95 ; \mathrm{H}, 4.11 ; \mathrm{N}, 3.47$; Cl, 8.61, ; F, 13.12, Calcd. for $\mathrm{C}_{22} \mathrm{H}_{17} \mathrm{ClF}_{3} \mathrm{NO}_{2}: \mathrm{C}, 62.94 ; \mathrm{H}, 4.08 ; \mathrm{N}$, $3.34 ; \mathrm{Cl}, 8.44 ; \mathrm{F}, 13.58 \% .{ }^{1} \mathrm{H}$ NMR $\left(\mathrm{CDCl}_{3}\right) \delta \mathrm{ppm}$ : $3.96(3 \mathrm{H}, \mathrm{s}), 4.95(2 \mathrm{H}, \mathrm{s}), 6.81(2 \mathrm{H}, \mathrm{d}, J=8.5 \mathrm{~Hz}), 7.14$ $(1 \mathrm{H}, \mathrm{dd}, J=7.6 \& 1.7 \mathrm{~Hz}), 7.26-7.29(2 \mathrm{H}, \mathrm{m}), 7.33-7.49$ $(6 \mathrm{H}, \mathrm{m}), 7.59(1 \mathrm{H}, \mathrm{d}, J=7.3 \mathrm{~Hz}) . \quad \mathrm{IR}(\mathrm{KBr}) \mathrm{cm}^{-1}: 3070$, 2940, 2900, 2820,1920,1610,1590, 1520, 1490, 1330, 1250, 1110, 1090, 1010, 980, 880, 830. Compound 12 ; Anal. Found : C, 63.02 ; H, 4.06 ; N, 3.37 ; Cl, 8.21, ; F, 13.45, Calcd. for $\mathrm{C}_{22} \mathrm{H}_{17} \mathrm{ClF}_{3} \mathrm{NO}_{2}: \mathrm{C}, 62.94 ; \mathrm{H}, 4.08 ; \mathrm{N}$,

Method A
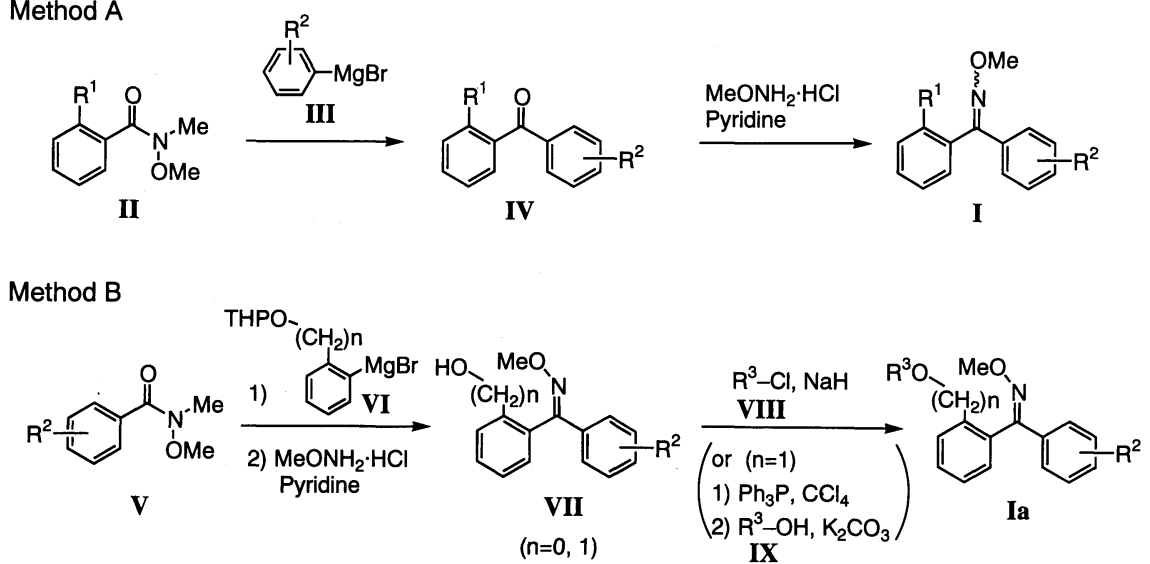

Fig. 2 Procedures for synthesis of benzophenone $O$-methyloximes. 
$3.34 ; \mathrm{Cl}, 8.44 ; \mathrm{F}, 13.58 \%{ }^{1} \mathrm{H}$ NMR $\left(\mathrm{CDCl}_{3}\right) \delta \mathrm{ppm}: 3.94$ $(3 \mathrm{H}, \mathrm{s}), 5.11(2 \mathrm{H}, \mathrm{s}), 6.88(2 \mathrm{H}, \mathrm{d}, J=9.0 \mathrm{~Hz}), 7.24-7.44$ $(8 \mathrm{H}, \mathrm{m}), 7.50(1 \mathrm{H}, \mathrm{d}, J=9.0 \mathrm{~Hz}), 7.57(1 \mathrm{H}, \mathrm{d}, J=7.3$ $\mathrm{Hz})$. IR (KBr) $\mathrm{cm}^{-1}: 3060,2940,2900,2820,1900$, $1610,1590,1520,1490,1330,1250,1160,1110,1070$, $1040,980,830$.

2.2 4'-Chloro-2-(5-trifluoromethyl-2-pyridyloxymethyl) benzophenone $O$-methyloxime : 21(Method B)

To a mixture of magnesium $(2.19 \mathrm{~g}, 90 \mathrm{mmol})$, bromoethane $(0.1 \mathrm{ml})$ and tetrahydrofuran $(5 \mathrm{ml})$ was added a solution of 1-bromo-(2-tetrahydropyranyloxymethyl)benzene $(16.27 \mathrm{~g}, 60 \mathrm{mmol})$ in tetrahydrofuran $(55 \mathrm{ml})$ at 50 to $55^{\circ} \mathrm{C}$ under a nitrogen atmosphere, and the mixture was stirred at 50 to $55^{\circ} \mathrm{C}$ for $1 \mathrm{hr}$ to prepare 2-(2-tetrahydropyranyloxymethyl)phenyl magnesium bromide (VI $; \mathrm{n}=1)$.

The Grignard reagent VI $(\mathrm{n}=1)$ was added to a solution of 4-chloro- $N$-methoxy- $N$-methylbenzamide $(\mathbf{V}$; $\left.\mathrm{R}^{2}=4-\mathrm{Cl} ; 5.99 \mathrm{~g}, 30 \mathrm{mmol}\right)$ in tetrahydrofuran $(30 \mathrm{ml})$ below $-60^{\circ} \mathrm{C}$ over $50 \mathrm{~min}$, and the mixture was stirred at $-50^{\circ} \mathrm{C}$ to room temperature for $2 \mathrm{hr}$. The reaction mixture was poured into ice-cold water $(100 \mathrm{ml})$ and saturated aqueous ammonium chloride solution $(50 \mathrm{ml})$, and extracted with ethyl ether $(100 \mathrm{ml} \times 2)$. The organic layer was washed with brine $(300 \mathrm{ml})$, dried over anhydrous magnesium sulfate and concentrated under reduced pressure. The residue was purified by silica gel column chromatography (ethyl acetate/hexane) to give $9.84 \mathrm{~g}$ (99\%) of 4'-chloro-2-(2-tetrahydropyranyloxymethyl)benzophenone as a colorless oil. ${ }^{1} \mathrm{H}$ NMR $\left(\mathrm{CDCl}_{3}\right) \delta$ ppm : 1.21-1.64 $(6 \mathrm{H}, \mathrm{m}), 3.39-3.48(1 \mathrm{H}, \mathrm{m}), 3.66-3.77$ $(1 \mathrm{H}, \mathrm{m}), 4.52(1 \mathrm{H}, \mathrm{d}, J=3.7 \mathrm{~Hz}), 4.58(1 \mathrm{H}, \mathrm{d}, J=12.8$ $\mathrm{Hz}), 4.82(1 \mathrm{H}, \mathrm{d}, J=12.8 \mathrm{~Hz}), 7.29-7.51(6 \mathrm{H}, \mathrm{m}), 7.73-$ $7.78(2 \mathrm{H}, \mathrm{m})$.

A mixture of 4'-chloro-2-(2-tetrahydropyranyloxymethyl)benzophenone $(3.31 \mathrm{~g}, 10 \mathrm{mmol})$, methoxylamine hydrochloride $(1.67 \mathrm{~g}, 20 \mathrm{mmol})$, pyridine $(1.74 \mathrm{~g}$, $22 \mathrm{mmol})$ and methanol $(20 \mathrm{ml})$ was heated under reflux with stirring for $5 \mathrm{hr}$. The mixture was poured into ice-cold water $(150 \mathrm{ml})$, acidified with $35 \%$ hydrochloric acid, and extracted with ethyl ether $(150 \mathrm{ml} \times 2)$. The combined organic layer was dried over anhydrous magnesium sulfate and concentrated under reduced pressure. The residue was purified by silica gel column chromatography (ethyl acetate / hexane) to give $2.31 \mathrm{~g}(84 \%)$ of $4{ }^{\prime}$-chloro-2-hydroxymethylbenzophenone $O$ methyloxime (VII ; $\left.\mathrm{R}^{2}=4-\mathrm{Cl}, \mathrm{n}=1\right)$ as a colorless oil. ${ }^{1} \mathrm{H}$ NMR $\left(\mathrm{CDCl}_{3}\right) \delta \mathrm{ppm}: 2.03(1 \mathrm{H}, \mathrm{t}, J=6.1 \mathrm{~Hz}), 3.97$ $(3 \mathrm{H}, \mathrm{s}), 4.46(2 \mathrm{H}, \mathrm{d}, J=6.1 \mathrm{~Hz}), 7.06-7.10(1 \mathrm{H}, \mathrm{m}), 7.27-$ $7.51(6 \mathrm{H}, \mathrm{m}), 7.58-7.61(1 \mathrm{H}, \mathrm{m})$. Oximation and following deprotection in situ of VI with methoxylamine hydrochloride and pyridine in methanol gave desired VII.

Sodium hydride ( $60 \%$ oil dispersion; $0.04 \mathrm{~g}, 1.0 \mathrm{mmol}$ ) was added to a mixture of VII $\left(\mathrm{R}^{2}=4-\mathrm{Cl}, \mathrm{n}=1 ; 0.22 \mathrm{~g}\right.$,
$0.8 \mathrm{mmol}$ ), 2-chloro-5-trifluoromethylpyridine (VIII; $\mathrm{R}^{3}=5$-trifluoromethyl-2-pyridyl ; $0.22 \mathrm{~g}, 1.2 \mathrm{mmol}$ ) and tetrahydrofuran $(2.4 \mathrm{ml})$ in an ice bath, and the mixture was stirred at room temperature for $5 \mathrm{hr}$. The reaction mixture was poured into ethyl ether $(100 \mathrm{ml})$ and washed with brine $(80 \mathrm{ml})$. The organic layer was dried over anhydrous magnesium sulfate and concentrated under reduced pressure. The residue was purified by silica gel column chromatography (ethyl acetate/hexane) to give $0.30 \mathrm{~g}$ (89\%) of compound $\mathbf{2 1}$ as a white solid, mp 57$58.5^{\circ} \mathrm{C}$. Anal. Found : C, $60.01 ; \mathrm{H}, 3.77 ; \mathrm{N}, 6.74 ; \mathrm{Cl}$, 8.25, ; F, 13.49, Calcd. for $\mathrm{C}_{21} \mathrm{H}_{16} \mathrm{ClF}_{3} \mathrm{~N}_{2} \mathrm{O}_{2}$ : C, 59.94 ; $\mathrm{H}, 3.83 ; \mathrm{N}, 6.66 ; \mathrm{Cl}, 8.42 ; \mathrm{F}, 13.54 \%{ }^{1} \mathrm{H}$ NMR $\left(\mathrm{CDCl}_{3}\right)$ $\delta \mathrm{ppm}: 3.95(3 \mathrm{H}, \mathrm{s}), 5.28(2 \mathrm{H}, \mathrm{s}), 6.54(1 \mathrm{H}, \mathrm{d}, J=8.0$ $\mathrm{Hz}), 7.11-7.14(1 \mathrm{H}, \mathrm{m}), 7.23-7.69(8 \mathrm{H}, \mathrm{m}), 8.29(1 \mathrm{H}, \mathrm{s})$. IR $(\mathrm{KBr}) \mathrm{cm}^{-1}: 3060,2940,2900,2820,1930,1610,1580$, $1500,1400,1330,1290,1270,1230,1080,1010,980,880$, 830.

\subsection{4'-Chloro-2-(4-phenylphenoxymethyl)benzo- phenone O-methyloxime : 11 (Method B)}

Carbon tetrachloride $(1.36 \mathrm{ml}, 14.4 \mathrm{mmol})$ was added to a mixture of VII $\left(\mathrm{R}^{2}=4-\mathrm{Cl}, \mathrm{n}=1 ; 1.65 \mathrm{~g}, 6.0 \mathrm{mmol}\right)$, triphenyl phosphine $(1.89 \mathrm{~g}, 7.2 \mathrm{mmol})$ and acetonitrile $(12 \mathrm{ml})$ in an ice bath, and the mixture was stirred at room temperature for $7 \mathrm{hr}$. The reaction mixture was concentrated under reduced pressure and the residue was purified by silica gel column chromatography (ethyl acetate/hexane) to give $1.47 \mathrm{~g} \mathrm{(83 \% )}$ of 4 '-chloro-2chloromethylbenzophenone $O$-methyloxime as a deep blue oil. ${ }^{1} \mathrm{H} \operatorname{NMR}\left(\mathrm{CDCl}_{3}\right) \delta \mathrm{ppm}: 3.96(3 \mathrm{H}, \mathrm{s}), 4.45$ $(2 \mathrm{H}, \mathrm{s}), 7.07(1 \mathrm{H}, \mathrm{dd}, J=7.9 \& 1.8 \mathrm{~Hz}), 7.26-7.49(6 \mathrm{H}$, $\mathrm{m}), 7.58(1 \mathrm{H}, \mathrm{dd}, J=7.3 \& 1.2 \mathrm{~Hz})$.

A mixture of $4^{\prime}$-chloro-2-chloromethylbenzophenone $O$-methyloxime $(0.29 \mathrm{~g}, 1.0 \mathrm{mmol})$, 4-phenylphenol (IX ; $\mathrm{R}^{3}=4$-biphenylyl ; $0.22 \mathrm{~g}, 1.3 \mathrm{mmol}$ ), potassium carbonate $(0.21 \mathrm{~g}, 1.5 \mathrm{mmol})$ and $N, N$-dimethylformamide $(2$ $\mathrm{ml}$ ) was stirred at $90^{\circ} \mathrm{C}$ for $7 \mathrm{hr}$. The reaction mixture was poured into water $(80 \mathrm{ml})$ and extracted with toluene $(100 \mathrm{ml})$. The organic layer was washed with brine $(80$ $\mathrm{ml}$ ), dried over anhydrous magnesium sulfate and concentrated under reduced pressure. The residue was purified by silica gel column chromatography (ethyl acetate/hexane) to give $0.27 \mathrm{~g}(63 \%)$ of compound $\mathbf{1 1}$. The product was recrystallized from ethyl acetate and hexane to give colorless crystals, $\mathrm{mp} 117-118^{\circ} \mathrm{C}$. Anal. Found : C, $75.87 ; \mathrm{H}, 5.15 ; \mathrm{N}, 3.39 ; \mathrm{Cl}, 8.19$, Calcd. for $\mathrm{C}_{27} \mathrm{H}_{22} \mathrm{ClNO}_{2}$ : C, $75.78 ; \mathrm{H}, 5.18 ; \mathrm{N}, 3.27 ; \mathrm{Cl}, 8.28 \%$. ${ }^{1} \mathrm{H}$ NMR $\left(\mathrm{CDCl}_{3}\right) \delta \mathrm{ppm}: 3.98(3 \mathrm{H}, \mathrm{s}), 4.95(2 \mathrm{H}, \mathrm{s})$, $6.81-6.87(2 \mathrm{H}, \mathrm{m}), 7.13(1 \mathrm{H}, \mathrm{dd}, J=7.8 \& 1.8 \mathrm{~Hz}), 7.37-$ $7.53(10 \mathrm{H}, \mathrm{m}), 7.66(1 \mathrm{H}, \mathrm{d}, J=6.6 \mathrm{~Hz}) . \quad$ IR $(\mathrm{KBr})$ $\mathrm{cm}^{-1}: 3060,3030,2940,2890,1920,1610,1520,1490$, $1240,1050,1010,980,880,830$. 


\section{Biological Tests}

3.1 Primary test : foliar application method for acaricidal activity

Test compounds were dissolved in a small amount of $N, N$-dimethylformamide and diluted to 500 to $15.6 \mathrm{ppm}$ with distilled water to give test suspensions. Fifteen adult female Tetranychus urticae were put onto the surface of kidney bean leaf (2-leaf stage) potted in a paper cup ( $7 \mathrm{~cm}$ in diameter, $6 \mathrm{~cm}$ in height) containing vermiculite, and kept at $25 \pm 1^{\circ} \mathrm{C}$ and $30-50 \%$ R.H. under continuous fluorescent light for $6 \mathrm{hr}$ to allow the mites to lay eggs. Then, the mites on kidney bean plants were sprayed with $10 \mathrm{ml}$ of test suspensions and kept under the conditions described above. The efficacy for control of the mites was evaluated two weeks after spraying, based on the area of plant injury caused by the mites and percentage relative to the control was calculated. The acaricidal activity was expressed as an index of A, B or C, corresponding to $95-100,70-94$ and 0-69\% control, respectively.

\subsection{Secondary test : leaf disc method for acaricidal activity}

Ten female adults of Tetranychus urticae and Tetranychus kanzawai were transferred onto kidney bean leaf discs ( $2 \mathrm{~cm}$ in diameter) and sprayed with $5.7 \mu$ $1 / \mathrm{cm}^{2}$ of test suspensions. The treated mites were kept at $25 \pm 1^{\circ} \mathrm{C}$ and $30-50 \%$ R.H. under continuous fluorescent light. Mortality was observed $48 \mathrm{hr}$ after treatment and the $\mathrm{LC}_{50}$ values were calculated by probit analysis.

\section{RESULTS AND DISCUSSION}

\section{Acaricidal Activities of Benzophenone $O$ - Methyloxime Derivatives}

The physical properties of the synthesized compounds and their acaricidal activities against $T$. urticae are listed in Tables 1 through 4.

\subsection{Effects of substituents $(X)$ on the phenoxymethyl moiety}

Table 1 shows the effects of substituent $(\mathrm{X})$ on the phenoxymethyl moiety of 4 '-chloro-2-(phenoxymethyl) benzophenone $O$-methyloximes on acaricidal activity. All of the compounds except 4-trifluoromethyl derivative (7) were less active or inactive against $T$. urticae, suggesting that a trifluoromethyl group at position-4 on the phenoxymethyl moiety was essential for exhibiting the activity.

\subsection{Comparison of geometrical or regio isomers}

The acaricidal activities of two geometrical isomers at the oxime moiety or three regio isomers at the phenoxymethyl moiety were compared by foliar application (Table 2). Geometrical configurational assignments of the oxime moiety were confirmed by chemical shifts of both methoxyimino protons $\left(=\mathrm{NOCH}_{3}\right)$ of the $E$ - and $Z$-isomers and $X$-ray diffraction analysis of compound 11 ( $Z$-isomer). The methoxyimino protons of the $Z$ -
Table 1 2-(Substituted phenoxymethyl)-4'-chlorobenzophenone $O$-methyloximes and their acaricidal activities against Tetranychus urticae.

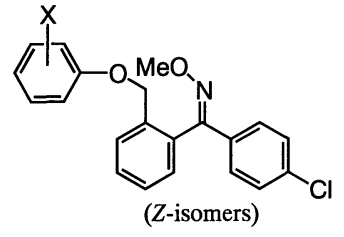

\begin{tabular}{ccccl}
\hline \multirow{2}{*}{$\begin{array}{c}\text { Compound } \\
\text { No. }\end{array}$} & $\mathrm{X}$ & $\mathrm{mp}\left({ }^{\circ} \mathrm{C}\right)$ or & \multicolumn{2}{c}{ Acaricidal activity } \\
\cline { 4 - 5 } & $n_{\mathrm{D}}\left({ }^{\circ} \mathrm{C}\right)$ & 500 & $250(\mathrm{ppm})$ \\
\hline $\mathbf{1}$ & $\mathrm{H}$ & Amorphous & $\mathrm{C}$ & - \\
$\mathbf{2}$ & $2-\mathrm{Cl}$ & $84-86$ & $\mathrm{C}$ & - \\
$\mathbf{3}$ & $3-\mathrm{Cl}$ & $88-90$ & $\mathrm{C}$ & - \\
$\mathbf{4}$ & $4-\mathrm{Cl}$ & $116-118$ & $\mathrm{C}$ & - \\
$\mathbf{5}$ & $2-\mathrm{CF}_{3}$ & $1.6078(24)$ & $\mathrm{C}$ & - \\
$\mathbf{6}$ & $3-\mathrm{CF}_{3}$ & $51-52$ & $\mathrm{C}$ & - \\
$\mathbf{7}$ & $4-\mathrm{CF}_{3}$ & $65.5-66.5$ & $\mathrm{~A}$ & $\mathrm{~A}$ \\
$\mathbf{8}$ & $4-\mathrm{Me}$ & $1.5798(24)$ & $\mathrm{C}$ & - \\
$\mathbf{9}$ & $4-t-\mathrm{Bu}$ & $1.5751(24)$ & $\mathrm{C}$ & - \\
$\mathbf{1 0}$ & $4-\mathrm{OCF}_{3}$ & $1.5634(24)$ & $\mathrm{C}$ & - \\
$\mathbf{1 1}$ & $4-\mathrm{Ph}$ & $117-118$ & $\mathrm{C}$ & - \\
\hline
\end{tabular}

a) Each activity is expressed as an index of A, B or C, corresponding to 95-100, 70-94 or 0-69\% control, respectively.

Table 2 Isomers of benzophenone $O$-methyloximes and their acaricidal activities against Tetranychus urticae.

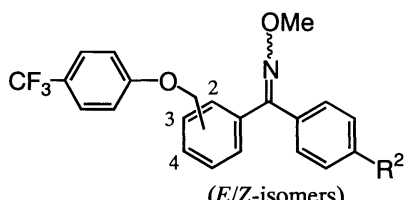

(E/Z-isomers)

\begin{tabular}{|c|c|c|c|c|c|c|c|}
\hline \multicolumn{2}{|l|}{ Compound } & \multirow[b]{2}{*}{$E / Z$} & \multirow{2}{*}{ Position } & \multirow{2}{*}{$\begin{array}{c}=\mathrm{NOCH}_{3} \\
{ }^{1} \mathrm{H} \text { NMR (ppm) }\end{array}$} & \multirow{2}{*}{$\begin{array}{c}\mathrm{mp}\left({ }^{\circ} \mathrm{C}\right) \text { or } \\
n_{\mathrm{D}}\left({ }^{\circ} \mathrm{C}\right)\end{array}$} & \multicolumn{2}{|c|}{ Acaricidal activity } \\
\hline No. & $\mathrm{R}^{2}$ & & & & & 500 & 250 (ppm) \\
\hline 12 & $\mathrm{Cl}$ & $E$ & 2 & 3.94 & $78-80$ & A & B \\
\hline 7 & $\mathrm{Cl}$ & $Z$ & 2 & 3.96 & $65.5-66.5$ & A & A \\
\hline 13 & $\mathrm{Cl}$ & $1 / 1$ & 3 & $3.96,3.98$ & $1.5750(24)$ & $\mathrm{C}$ & - \\
\hline 14 & $\mathrm{Cl}$ & $1 / 1$ & 4 & $3.97,3.98$ & $1.5780(24)$ & $\mathrm{C}$ & - \\
\hline 15 & $\mathrm{~F}$ & $E$ & 2 & 3.94 & $44-46$ & B & - \\
\hline 16 & $\mathrm{~F}$ & $Z$ & 2 & 3.95 & $1.5560(24)$ & A & $\mathrm{C}$ \\
\hline 17 & $\mathrm{~F}$ & $1 / 1$ & 3 & $3.97,3.99$ & $1.5598(24)$ & $\mathrm{C}$ & - \\
\hline 18 & $\mathrm{~F}$ & $1 / 1$ & 4 & $3.96,3.99$ & $79-80$ & $\mathrm{C}$ & - \\
\hline
\end{tabular}

a) Each activity is expressed as shown in Table 1.

isomers (cis to phenoxymethyl moiety) resonate in a lower magnetic field than those of the $E$-isomers (trans to phenoxymethyl moiety). In the case of 4-chloro and 4-fluoro derivatives, $Z$-isomers (7 and 16) were more active than $E$-isomers (12 and 15). Among the regio isomers $(7,13,14,16-18)$, ortho isomers (7 and 16) 
showed good acaricidal activities, whereas meta (13 and 17) and para (14 and 18) isomers were unfavorable. The results in regard to geometry or location of substituents $\left(\mathrm{R}^{1}=4\right.$-trifluoromethylphenoxymethyl) on the benzene ring were similar to those of 2-alkoxyimino-2phenylacetamide derivatives to obtain higher biological activities. ${ }^{3)}$

\subsection{Effects of substituents $\left(R^{1}\right)$ on the left phenyl moiety}

Since 2-(4-trifluoromethylphenoxymethyl)benzophenone $O$-methyloximes were found to be favorable compounds for acaricidal activity, the phenoxymethyl moiety of compound $\mathbf{7}$ was modified structurally. Table 3 shows the effects on the acaricidal activity of various substituent $\left(\mathrm{R}^{1}\right)$ at position-2 on the left phenyl moiety of these derivatives. Among these derivatives, a pyridyloxymethyl derivative (21) showed higher acaricidal activity than compound $\mathbf{7}$, but all the others were less active or inactive.

The acaricidal activity of compound 7 was promoted by replacing its benzene ring in $\mathrm{R}^{1}$ with a pyridine ring as in 5-trifluoromethyl-2-pyridyl derivative (21). These results suggested that the physicochemical characteristics or electronic influences of the pyridine ring might lead to enhancement of the activity, whereas definitive reasons have not been obtained so far..$^{5,6)}$

\subsection{Effects of substituents $\left(R^{2}\right)$ on the right phenyl moiety}

Table 4 shows the effects on the acaricidal activity of

Table 3 2-Substituted 4'-chlorobenzophenone $O$ methyloximes and their acaricidal activities against Tetranychus urticae.

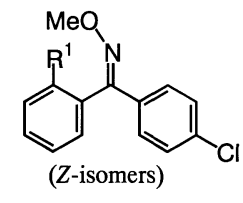

\begin{tabular}{|c|c|c|c|c|c|}
\hline \multirow{2}{*}{$\begin{array}{c}\text { Compound } \\
\text { No. }\end{array}$} & \multirow[b]{2}{*}{$\mathrm{R}^{1}$} & \multirow{2}{*}{$\begin{array}{c}\mathrm{mp}\left({ }^{\circ} \mathrm{C}\right) \text { or } \\
n_{\mathrm{D}}\left({ }^{\circ} \mathrm{C}\right)\end{array}$} & \multicolumn{3}{|c|}{ Acaricidal activity ${ }^{\text {a) }}$} \\
\hline & & & 500 & 250 & $62.5(\mathrm{ppm})$ \\
\hline 19 & & $88-90$ & $\mathrm{C}$ & - & - \\
\hline 7 & & $65.5-66.5$ & A & A & C \\
\hline 20 & & $110-111$ & $\mathrm{C}$ & - & - \\
\hline 21 & & $57-58.5$ & A & A & A \\
\hline 22 & & $89-91$ & $\mathrm{C}$ & - & - \\
\hline 23 & & $62-64$ & $\mathrm{C}$ & - & - \\
\hline 24 & & $1.5701(24)$ & $\mathrm{C}$ & - & - \\
\hline
\end{tabular}

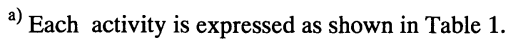

various substituents $\left(\mathrm{R}^{2}\right)$ on the right phenyl moiety of 2-(5-trifluoromethyl-2-pyridyloxymethyl)benzophenone $O$-methyloximes. Substitution with a fluoro or a chloro group at position- $4^{\prime}$ of the phenyl ring (28 or $\mathbf{2 1}$ ) resulted in the most favorable acaricidal activities, while substitution at position-3' (27 and 30) or - $2^{\prime}$ ( 26 and 29) resulted in weak or no activity. Among compounds with a substituent at position- $4^{\prime}$ of the phenyl ring $(\mathbf{2 1}, \mathbf{2 8}, \mathbf{3 1}-$ 39), chloro (21), bromo (33) and trifluoromethyl (34) derivatives were most active, followed by fluoro (28), nitro (36) and cyano (37) derivatives. Hydrogen (25), methyl (31), methoxy (32), phenyl (38) and phenoxy (39) derivatives showed reduced acaricidal activities. These findings suggested that the presence of an electronwithdrawing effect of the substituent at position- $4^{\prime}$ on the right phenyl moiety may be essential for the activity.

\section{Acaricidal Activities of Selected Compounds}

From the results described above, compounds 21 and 34 were selected for further evaluation (leaf disc test). Compound 21 showed about twice the acaricidal activities of the commercially available acaricide pyridaben to T. urticae, while about 4 times to T. kanzawai (Table 5). Furthermore, compound $\mathbf{2 1}$ showed not an acute toxicity

Table 4 2-(5-Trifluoromethyl-2-pyridyloxymethyl)benzophenone $O$-methyloximes and their acaricidal activities against Tetranychus urticae.

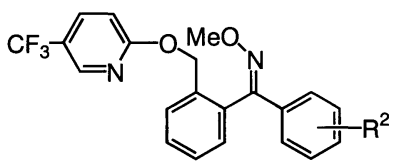

(Z-isomers)

\begin{tabular}{|c|c|c|c|c|c|c|}
\hline \multirow{2}{*}{$\begin{array}{c}\text { Compound } \\
\text { No. }\end{array}$} & \multirow[b]{2}{*}{$\mathrm{R}^{2}$} & \multirow{2}{*}{$\begin{array}{c}\mathrm{mp}\left({ }^{\circ} \mathrm{C}\right) \text { or } \\
n_{\mathrm{D}}\left({ }^{\circ} \mathrm{C}\right)\end{array}$} & \multicolumn{4}{|c|}{ Acaricidal activity ${ }^{\text {a) }}$} \\
\hline & & & 500 & 250 & 62.5 & $15.6(\mathrm{ppm})$ \\
\hline 25 & $\mathrm{H}$ & $1.5665(24)$ & $\mathrm{C}$ & - & - & - \\
\hline 26 & $2-\mathrm{F}$ & $40-55^{b)}$ & $\mathrm{C}$ & - & - & - \\
\hline 27 & $3-\mathrm{F}$ & $1.5499(24)$ & B & - & - & - \\
\hline 28 & $4-\mathrm{F}$ & $72-73$ & A & A & B & $\mathrm{C}$ \\
\hline 29 & $2-\mathrm{Cl}$ & $55-56$ & $\mathrm{C}$ & - & - & - \\
\hline 30 & $3-\mathrm{Cl}$ & $39-41$ & $\mathrm{C}$ & - & - & - \\
\hline 21 & $4-\mathrm{Cl}$ & $57-58.5$ & A & A & A & A \\
\hline 31 & 4-Me & $49-51$ & $\mathrm{C}$ & - & - & - \\
\hline 32 & 4-OMe & $1.5679(24)$ & $\mathrm{C}$ & - & - & - \\
\hline 33 & $4-\mathrm{Br}$ & $55.5-56.5$ & A & A & A & B \\
\hline 34 & $4-\mathrm{CF}_{3}$ & $1.5280(24)$ & A & A & A & B \\
\hline 35 & $4-\mathrm{OCF}_{3}$ & $1.5219(24)$ & A & B & B & $\mathrm{C}$ \\
\hline 36 & $4-\mathrm{NO}_{2}$ & $111-113$ & A & A & B & $\mathrm{C}$ \\
\hline 37 & $4-\mathrm{CN}$ & $87-88$ & A & A & B & $\mathrm{C}$ \\
\hline 38 & 4-Ph & $1.6062(24)$ & $\mathrm{C}$ & - & - & - \\
\hline 39 & 4-OPh & $1.5861(24)$ & $\mathrm{C}$ & - & - & - \\
\hline
\end{tabular}

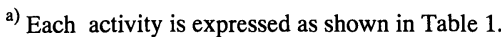

b) An $E / Z$ mixture with approximate ratio of $6: 4$ as determined from its ${ }^{1}$ H NMR spectrum. 
Table 5 Acaricidal activities of selected compounds.

\begin{tabular}{ccc}
\hline \multirow{2}{*}{ Compound } & \multicolumn{2}{c}{$\mathrm{LC}_{50}(\mathrm{ppm})$} \\
\cline { 2 - 3 } & $\mathrm{TU}$ & $\mathrm{TK}$ \\
\hline $\mathbf{2 1}$ & 16.4 & 9.0 \\
$\mathbf{3 4}$ & 24.8 & 7.2 \\
Pyridaben $^{\mathrm{a})}$ & 34.5 & 33.7 \\
\hline
\end{tabular}

TU: Tetranychus urticae, TK: Tetranychus kanzawai.

a) Sanmite ${ }^{\circledR}$ 20\% WP (Nissan Chemical Industries, Ltd.).

against mice $\left(\mathrm{LD}_{50}>300 \mathrm{mg} / \mathrm{kg}\right)$ and a lower toxicity against Oryzias latipes $\left(\mathrm{LC}_{50}>10 \mathrm{ppm}\right)$.

As these compounds showed no inhibitory effects on oxygen consumption by submitochondrial particles in a cell-free system, the binding site of the benzophenone $O$-methyloximes seems to be different from that of alkoxyiminoacetamides (unpublished). ${ }^{7)}$ The results of the present study demonstrated that the 2-(5trifluoromethyl-2-pyridyloxymethyl)benzophenone $O$ methyloximes, a new class of acaricide, are highly effective compounds against $T$. urticae and T. kanzawai.

\section{ACKNOWLEDGMENTS}

We wish to express our thanks to Dr. Reiji Takeda, Director of Aburahi Laboratories, Shionogi \& Co., Ltd., for encouragement and permission to publish this work. We also wish to thank Drs. Toshikazu Ohtuska and Akira Mizutani for invaluable discussions and encouragement.

\section{REFERENCES}

1) H. Kai, T. Ichiba, M. Miki, A. Takase \& M. Masuko: $J$. Pesticide Sci. 24, 130 (1999)
2) H. Kai, T. Ichiba, M. Tomida \& M. Masuko: J. Pesticide Sci. 24, 149 (1999)

3) T. Kataoka, Y. Hayase, M. Masuko, M. Niikawa, M. Ichinari, H. Takenaka, N. Tanimoto, Y. Hayashi \& R. Takeda: J. Pesticide Sci. 23, 95 (1998)

4) H. Takenaka, M. Ichinari, N. Tanimoto, Y. Hayase, M. Niikawa, T. Ichiba, M. Masuko, Y. Hayashi \& R. Takeda: J. Pesticide Sci. 23, 107 (1998)

5) H. Takenaka, Y. Hayase, R. Hasegawa, T. Ichiba, M. Masuko, A. Murabayashi \& R. Takeda: J. Pesticide Sci. 23, 379 (1998)

6) H. Haga, K. Fujikawa, N. Sakashita \& R. Nishiyama: $J$. Pesticide Sci. 12, 311 (1987)

7) A. Mizutani, H. Yukioka, H. Tamura, N. Miki, M. Masuko \& R. Takeda: Phytopathology 85, 306 (1995)

\section{要 約

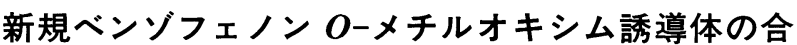 成と殺ダニ活性}

甲斐浩幸，冨田 実，中井 徹，熊野きぬ子 廣瀬茂樹，森田幸一

新規なベンゾフェノン $O$-メチルオキシム誘導体を合成 し，それらの殺ダ二活性を評価した。困と活性の相関性を 調べた結果，左側のフェニル基 2 位の置換基は，5-トリフ ルオロメチル-2-ピリジルオキシメチル基を導入した化合 物が最も高い殺ダニ活性を示した. $O$-メチルオキシム部分 の幾何異性体間の活性を比較した場合, $Z$ 体の方が $E$ 体よ り高かった。 また，右側のフェニル基の置換基は，4'-ク口 ロ，4'-ブロモ，4'-トリフルオロメチル基で置換した場合に 高い活性を示した。 中でも，4'-クロロ-2-(5-トリフルオロ

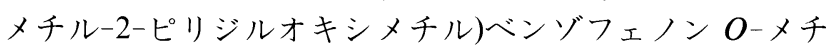
ルオキシム(21)は，十ミハダニおよびカンザワハダニに対 して優れた活性を示した. 